\title{
PRESENTACIÓN DE LOS EDITORES
}

Hay servicios y encargos que convocan a la alegría, la satisfacción y la gratitud. Preparar y coordinar, en nuestro caso como editores, una entrega monográfica de Revista de Fomento Social, es uno de esos servicios. Lo ha sido también para todos a quien hemos invitado y se han sumado a este homenaje, sea con sus escritos, sea en la Tabula gratulatoria, lo ha sido para la propia revista y lo es para las instituciones, la Universidad Loyola Andalucía, como editora y última responsable académica de la Revista de Fomento Social, y la Compañía de Jesús de España que la confió a INSA-ETEA en 1991.

José Juan Romero Rodríguez S. I. cumple en estos días finales de 2017 su septuagésimoquinto aniversario y es profesor de la Universidad Loyola Andalucia, emérito tras su jubilación en 2007, después de haber ejercido su magisterio treinta y siete años en ETEA, Facultad de Ciencias Económicas y Empresariales, adscrita a la Universidad de Córdoba. Entre julio de 2000 y diciembre de 2008 fue director de la Revista de Fomento Social.

Para reconocer un servicio intelectual tan dilatado en nuestra institución, la Revista de Fomento Social quiere ofrecer este Liber amicorum de la comunidad intelectual y humana de la Universidad Loyola Andalucía, en el que también participan antiguos compañeros de ETEA y de otros centros universitarios, entre ellos la Universidad de Córdoba. A través de las colaboraciones escritas y de las adhesiones testimoniales se explica por sí mismo un homenaje como éste. No se requiere más.

La portada reproduce un grabado poco conocido de finales del siglo XVIII, que invita a aprender a mirar el mundo de otra manera. Aunque la mayoría de los autores colaboradores se han ajustado a las dimensiones indicadas, no siempre ha podido ser así por diversas razones. Estaba previsto un ejemplar de Revista de Fomento Social más pequeño en grosor, pero finalmente todos hemos sido beneficiados por la rica pluralidad resultante. En la versión electrónica disponible en www. revistadefomentosocial.es pueden consultarse con provecho los gráficos y mapas en color que aparecen en alguna contribución.

Hemos presentado los escritos en cuatro grandes partes que engloban, como es usual, los cuatro centros de interés del trabajo docente, investigador y público del profesor Romero: el desarrollo, la cooperación internacional y la integración regional, especialmente referidas a la Unión Europea y a Centroamérica, el desarrollo rural y, 
por último, la educación, la empresa y la universidad como parte de la misión de la Compañía de Jesús.

José M. Margenat Peralta S. I. y Adolfo Rodero Franganillo, editores del Liber amicorum

\section{PRESENTATION of the editors}

There are services and assignments that summon us to gladness, satisfaction and gratitude. To prepare and coordinate, in our case as editors, a monograph number of the Fomento Social Review, is one of those services. Likewise it is as well a service of all those whom we have invited and have added themselves to this homage, may it be with their articles, or in the Tabula gratulatoria, it has also been a service for the very review itself, and it is indeed a service for the institutions: the University Loyola Andalusia, as editing entity and ultimate academic responsible for the Fomento Social Review, and for the Society of Jesus of Spain, which entrusted it to INSA-ETEA in 1991.

José Juan Romero Rodríguez, S. I., on these final days of 2017 completes his seventy-fifth anniversary, and is a professor of the University Loyola Andalusia, emeritus since his retirement in 2007, after having practiced his teaching during thirty seven years at ETEA, the Faculty of Economic and Management Sciences attached to the University of Córdoba (Spain). Between July 2000 and December 2008, he was Director of the Fomento Social Review.

In order to acknowledge a so vast intellectual service in our institution, the Fomento Social Review wishes to offer this Liber amicorum of the intellectual and human community of the University Loyola Andalusia, in which also old colleagues of ETEA and of other university centers as well have taken part, among them the University of Córdoba. Through the written collaborations and the support messages, a homage such as this one, is explained by itself. No more is required.

The front cover reproduces a scarcely known engraving of the late XVIIIth century, that invites us to contemplate the world in a different way. Although most of the collaborating authors have adjusted themselves to the required dimensions, not always has it been possible to do so, for several reasons. A number of Fomento Social Review, smaller in thickness, was foreseen, but finally all of us have benefitted by the actual rich plurality. In the electronic edition, available at www.revistadefomentosocial.es the bar charts and color maps appearing in some of the collaborations, profitably can be consulted.

We are presenting the writings in four great parts that comprise, as it is natural, the four centers of interest of professor Romero's teaching work, research and his public: development, international cooperation, and regional integration, referred especially to the European Union and to Central America, the rural development, and lastly, education, the enterprise and the university, as part of the mission of the Society of Jesus.

José M. Margenat Peralta S. I. and Adolfo Rodero Franganillo, editors of the Liber amicorum. 